\title{
Development of COVID-19 Neutralizing Antibody (NAb) Detection Kits Using the S1 RBD Protein of SARS-CoV-2
}

Dong Ok Choi, Kang Moon Lee

Department of Chemical Engineering \& Biotechnology, Korea Polytechnic University, Siheung, Korea

\section{코로나 바이러스 감염증-19의 재조합 S1 RBD 단백질을 이용한 COVID-19 바이러스의 중화항체 검사 키트의 개발}

최동옥, 이강문

한국산업기술대학교 생명화학공학과

\section{ARTICLE INFO}

\section{Received July 3, 2021}

Revised $1^{\text {st }}$ August 16, 2021

Revised $2^{\text {nd }}$ August 20, 2021

Accepted August 22, 2021

\begin{abstract}
The COVID-19 virus is a $\beta$-genus virus that causes infection by mediating the angiotensin convertible enzyme 2 (ACE2) receptor, which is distributed in large numbers in the human respiratory tract. The disease requires effective post-management of antibody production by complete healers and vaccinators because there is no perfect remedy for the virus infection. This study aimed to develop recombinant proteins specifically responsive to neutralizing antibodies in clinical specimens and use them to develop a rapid diagnostic kit to diagnose neutralizing antibodies quickly and conveniently against the COVID-19 virus and confirm the possibility of commercialization through a performance evaluation. Rapid diagnostic kits using COVID-19 S1 RBD recombinant proteins can be applied to rapid diagnostic kits, with positive percentage agreement (PPA) and negative percentage agreement (NPA) of $100 \%$ and $98.3 \%$, respectively, compared to the U.S. FDA-approved ELISA kits. If the performance of the rapid diagnostic kit is improved and neutralizing antibodies can be analyzed quantitatively using quantitative analysis equipment, it can be used as important data to predict immunity to the COVID-19 virus and determine additional vaccinations.
\end{abstract}

Copyright (C) 2021 The Korean Society for Clinical Laboratory Science. All rights reserved.

\section{서 론}

기존의 코로나 바이러스는 외막을 갖는 양성 센스(positivesense), 단일 가닥, RNA 바이러스로서 사람에게 감염 시 가벼 운 호흡기성 질환을 일으킨다고 알려져 있었으나, 2019년 말 중 국의 한 병원에서 처음 학계에 보고된 호흡기 질환을 유발하는 코로나바이러스는 중증 급성 호흡기 증후군 코로나바이러스 2,

Corresponding author: Kang Moon Lee

Department of Chemical Engineering \& Biotechnology, Korea Polytechnic

University, 237 Sangidaehak-ro, Siheung 15073, Korea

E-mail: leekm@kpu.ac.kr

ORCID: https://orcid.org/0000-0001-6952-9314 severe acute respiratory syndrome-coronavirus-2 (SARS$\mathrm{CoV}-2$ ) 또는 코로나-19 (COVID-19)라는 이름으로도 불린다 [1, 2]. 2021년 3월 17일까지 보고된 확진 수는 약 1.21 억명, 사 망자는 약 268만명에 육박한다. 확진 환자가 가장 많이 발생한 대륙은 미대륙, 유럽, 동남아시아순이며 각 대륙에서의 확인된 누계 확진 환자수는 각 $53,160,109$ 명, $41,563,117$ 명, 그리고 $13,986,486$ 명으로 집계된다. 또한 국가 기준으로 해당 바이러 스감염 확진 환자 수는 미국, 브라질, 인도가 상위 세 곳으로 각 국가에서 29,605,933명, 11,693,838명, 그리고 $11,474,605$ 명 의 COVID-19감염에 의한 확진 환자가 발생했다는 것이 확인 되었다[3, 4]. 
공기중의 비말 내 포함된 바이러스에 의한 감염 전파가 COVID-19의 주된 전파 경로로 밝혀짐에 따라 [5, 6, COVID19 가 '어떻게 급성 호흡기 감염 및 질환을 유발하는지'에 대한 연구 또한 집중적으로 이루어졌다. 이를 통해 연구자들은 COVID-19가 2002년부터 2003년까지 유행한 SARS-CoV와 같은 $\beta$-genus에 속한다는 것과, 신종 코로나 바이러스 또한 envelope-anchored spike 단백질을 매개한 숙주 수용체와 의 결합 및 '세포내 이입(endocytosis)' 이 주된 감염의 시작 경 로임을 밝혀냈다[7]. 또한 SARS-CoV와마찬가지로 COVID-19 는 angiotensin-converting enzyme 2 (ACE2)를 주요 수용 체 매개하여 숙주와 융합하고, 해당 수용체가 가장 많이 분포하 고 있는 호흡기 내 폐포의 ‘폐상피세포'를 통한 감염이 주된 전파 경로임을 확인하였다[7, 8]. 또한 COVID-19의 수용체로 작용 하는 ACE2에 매개되는 바이러스의 항원성 단백질은 바이러스 의 여러 단백질 중 spike (S)단백질로서 이 단백질은 subunit 1 (S1)과 subunit 2 (S2)로 이루어졌으며 두 종류의 소단위 단백 질은 각각, S1은 숙주 세포로의 결합과 S2는 세포막과 바이러스 의 융합에 관여하는 것으로 알려져 있다[9].

이러한 정보에 따라 현재 한국을 포함하는 여러 국가에서 허 가를 받아 국민들에게 접종 중에 있는 백신들은 주요 감염경로 에 작용하는 COVID-19 바이러스의 S1 RBD 단백질에 결합하 는 중화 항체를 생성시켜 바이러스의 S1 RBD 단백질과 숙주세 포의 ACE2의 결합을 방해함으로써 숙주세포로의 침입을 막는 역할을 한다. 특히 한국에서 현재 접종 중에 있는 아스트라제네 카, 화이자, 얀센 백신은 바이러스 항원 유전자를 체내에 투여하 여 접종자가 COVID-19에 대하여 면역활성을 갖도록 유도하 는 백신으로서, 접종자는 COVID-19의 감염 없이도 바이러스 가 세포로 침투하는 기전을 막는 항체를 생성할 수 있게 된다 [10-13].

현재까지 상기의 COVID-19 백신 접종자 및 감염환자에게 서 중화항체가 생성되었는지 확인하는 방법으로 가장 널리 쓰이 는 방식은 conventional virus neutralization test (cVNT) 방법 혹은 pseudovirus-based virus neutralization test (pVNT) 방법으로 시험한 검체 내의 COVID-19 바이러스에 대 한 중화항체 양에 대하여 정확하게 확인할 수 있다[14]. 그러나 이러한 방법들은 고위험군의 바이러스를 직접적으로 사용하기 위한 시설을 갖추어야 하고, 시설을 이미 갖추었다 하더라도, 최 종 결과를 얻기까지 최소 48시간에서 최대 96시간이 필요한 방 법이기에 감염자 혹은 백신 접종자에 대한 효율적인 사후 관리 와 백신 완전 접종 이후 사후 역학조사에 대하여 해당 방법을 적 용하기 적절치 않다.
따라서 본 논문을 통하여 우리가 연구하고자 하는 것은 중화 항체에 특이적인 항원 및 이를 활용한 측방유동 면역크로마토그 래피법, lateral flow immunoassay (LFA)에 대한 것으로, COVID-19 바이러스가 사람의 ACE2에 결합하는 데 있어 중요 한 역할을 하는 COVID-19S1 RBD 단백질에 대한 재조합 항원 을 제작하는 것이 첫째 목표다. 또한 이렇게 개발한 재조합 항원 을 사용하여 개발한 신속진단키트의 감염자 또는 백신 접종자의 혈액에 존재하는 중화항체에 대한 성능학적 지표인 특이도와 민 감도를 확인하고자 한다.

\section{재료 및 방법}

\section{1. 유전 물질 제작}

COVID-19 바이러스의 RBD영역은 NCBI (MD, USA)에서 염기서열에 대한 정보를 검색하였으며 유전자 합성을 통하여 $\mathrm{DNA}$ 를 확보하였다. COVID-19 바이러스 S1 RBD 유전자와 pCMV vector plasmid (Sino Biological, Beijing, China) 에 삽입하였다. Plasmid로의 삽입 시, 5' 말단에는 Hind III (AAGCTT) 제한효소를, 3'말단에는 Kpn I (GGTACC) 제한효 소 절단부위를 포함하도록 설계하였다. COVID-19 바이러스S 단백질 유전자를 주형 DNA로 사용하여 PCR 반응을 수행하였 고 증폭된 재조합 plasmid는 열충격방법을 통해 Escherichia coli DH5 $\alpha$ competent cell의 형질전환에 사용되었다. 이러한 E. coli $\mathrm{DH} 5 \alpha$ competent cell은 가나마이신 $(40 \mu \mathrm{g} / \mathrm{mL})$ 이 포 함된 $\mathrm{LB}$ 평판배지에 도말하여 $37^{\circ} \mathrm{C}$ 배양기에서 16 시간 이상 배양하였다. 평판배지에 완전히 자란 단일 콜로니를 취하여 가 나마이신 $(40 \mu \mathrm{g} / \mathrm{mL})$ 이 포함된 LB 액체배지에 넣고 $180 \mathrm{rpm}$ 의 속도로 Innova 4230 배양기(New Brunswick, Arlington, UK)에서 16시간 배양하였으며, Plasmid prep kit (뉴클레오 젠, 경기도, 한국)를 사용하여 plasmid purification을 수행하 였으며 유전자분석을 통하여 서열을 확인하였다.

\section{2. 세포 배양 및 형질전환}

HEK293 (human embryonic kidney) 세포는 70 90\% 밀집도에서 트립신-EDTA (0.05\%) 용액(ThermoFisher, MA, USA)을 사용하여 계대배양을 하였으며, $10 \%$ fetal bovine serum; FBS (Sigma-Aldrich, MO, USA)가 포함된 Dulbecco modified eagle medium F12; DMEM/F12 (Pan Biotech, Aidenbach, Germany)을 사용하여 $1.0 \times 10^{5} \mathrm{cells} / \mathrm{mL}$ 이 되 도록 세포를 조절하였다. 이를 $5 \% \mathrm{CO}_{2}$ 및 높은 습도로 유지되 는 $37^{\circ} \mathrm{C}$ 인큐베이터에서, $100 \mathrm{unit} / \mathrm{mL}$ 페니실린 및 100 
$\mu \mathrm{g} / \mathrm{mL}$ 스트렙토마이신을 포함하는 배지로 주기적으로 교체하 며 배양하였다. 형질전환을 위해 Lipofectamine 2000 (Invitrogen, MA, USA)을 사용하였으며, 형질전환 이후 $10 \% \mathrm{FBS}$ 와 $100 \mu \mathrm{g} / \mathrm{mL}$ hygromycin이 포함된 DMEM/F12를 사용하 여 배양하였고 형질전환 된 세포 중 RBD 단백질을 발현하는 well의 세포를 선택하여 계대배양하면서 FBS가 포함된 배지에 무혈청 배지의 양을 점차증가시켜 세포를 무혈청배지에 적응시 켜서 최종 $100 \%$ 무혈청 배지에서 계대배양하였다.

\section{3. 단백질 회수 및 확인}

형질 전환된 세포의 배양액을 회수하여 필터 처리한 후 회수 한 배지 부피의 $15 \%$ 농도가 되도록 황산암모늄(Samchun, Pyeongtaek, Korea)을 첨가한 후상층액을 회수하였다. 이를 $4^{\circ} \mathrm{C}$ 에서 하루동안 정지한 후에 다시 $9,000 \times \mathrm{g}$ 로 원심분리를 수행하였다. 펠렛에 $10 \mathrm{mM}$ 인산염완충액(phosphate buffered saline)을 넣은 후 재현탁하고, 마지막으로 $4^{\circ} \mathrm{C}$ 에서 10,000 $\times \mathrm{g}$ 로 30 분간 원심분리하여 회수한 상층액을 $0.45 \mu \mathrm{m}$ 필터 (Merck Millipore, MA, USA)로 걸러주었다. RBD 재조합 항 원의 정제는 친화 크로마토그래피법을 통해 이루어졌으며, 정 제에는 Ni sepharose 레진(GE Healthcare, IL, USA)을 사용 하였다. 또한 세척액을 레진에 투과시켜 RBD 단백질 이외의 단 백질을 제거하였고, 이후 용출완충액을 처리하여 레진에 흡착 되어 있는 RBD 단백질을 용출하였다. 용출된 RBD 단백질을 $10 \mathrm{mM}$ 인산염완충액을 사용하여 $4^{\circ} \mathrm{C}$ 에서 3시간씩 2회 투석 한 후 마지막 투석은 $4^{\circ} \mathrm{C}$ 에서 하룻밤동안 투석한 후에 회수하였 다. 단백질의 크기는 SDS-PAGE를 실행하여 확인하였으며,
Mini Protean 3 system (Bio-Rad, CA, USA)에서 12\% separating gel을 사용하였다. 겔은 $150 \mathrm{~V}$ 에서 1 시간 동안 전기 영동하였으며, 전기영동이 끝난 후에는 coomassie brilliant blue R-250 (Merck Millipore, MA, USA) 염색하여 확인하였 다. 또한 이를 통해 회수한 단백질의 순도를 검사하기 위하여 GenAnalyzer 19.1; gel 분석 소프트웨어를 사용하여 확인하 였다.

\section{Membrane blotting을 통한 항원의 특이도 검사}

‘10.3’을 통해 회수한 단백질과 구입한 RBD 단백질(바이오 앱, 경상북도, 한국)의 $\mathrm{RBD}$ 특이 항체에 대한 반응성을 검증하 기 위하여, COVID-19 바이러스성 S1 RBD 단백질에 대한 항 체 clone\#B3D4 (Bore Da Biotech, Seongnam, Korea)를 사용한 spot blot과 western blot을 모두 실험 진행하여, 입체 구조의 단백질 및 denature 형태의 재조합 단백질이 COVID19 S1 RBD 단백질에 대한 항체에 대하여 반응하는지 확인하였 다.

\section{LFA를 통한 재조합 항원의 민감도와 특이도 검사}

개발한 재조합 항원의 COVID-19 바이러스의 중화항체에 대한 특이도를 시험하기 위하여 LFA 형태로 제작하였으며, 키 트의 membrane에는 control line에 goat anti-chicken IgY과 test line에 recombinant COVID-19 S1 RBD 단백질 을 $1 \mathrm{mg} / \mathrm{mL}$ 농도로 분주하였다. NIBSC (Herts, UK)와 Precision for Medicine (MA, USA)에서 구입한 COVID-19 중화항체 양성(Table 1) 및 음성 검체를(Table 2) 사용하여 재

Table 1. The NAb concentrations of the tested 37 positive samples from NIBSC

\begin{tabular}{|c|c|c|c|c|c|}
\hline Panel No. & $\begin{array}{l}\text { Concentration } \\
(\mathrm{AU} / \mathrm{mL})\end{array}$ & Panel No. & $\begin{array}{l}\text { Concentration } \\
(\mathrm{AU} / \mathrm{mL})\end{array}$ & Panel No. & $\begin{array}{c}\text { Concentration } \\
(\mathrm{AU} / \mathrm{mL})\end{array}$ \\
\hline 1 & 16.9 & 14 & 69.2 & 27 & $<3.80$ \\
\hline 2 & 29.1 & 15 & 102 & 28 & $<3.80$ \\
\hline 3 & 222 & 16 & 71.5 & 29 & $<3.80$ \\
\hline 4 & 142 & 17 & 94.8 & 30 & $<3.80$ \\
\hline 5 & 192 & 18 & 102 & 31 & $<3.80$ \\
\hline 6 & 57.4 & 19 & 118 & 32 & $<3.80$ \\
\hline 7 & 82.3 & 20 & 113 & 33 & $<3.80$ \\
\hline 8 & 142 & 21 & 103 & 34 & $<3.80$ \\
\hline 9 & 168 & 22 & 121 & 35 & 8.43 \\
\hline 10 & 140 & 23 & 122 & 36 & $<3.80$ \\
\hline 11 & 54.3 & 24 & $<3.80$ & 37 & $<3.80$ \\
\hline 12 & 67 & 25 & $<3.80$ & & \\
\hline 13 & 67 & 26 & $<3.80$ & & \\
\hline
\end{tabular}

The measured concentration of NAb within samples ordered from NIBSC. These NAb containing samples werediluted into $10 \%$ with $1 X$ PBS to calibrate clinical efficacy of the devised kits. 
조합 항원의 성능을 확인하였다. 양성 샘플의 중화항체 농도에 관련한 정보는 NIBSC를 통해 제공되었으며, 음성 검체는 Precision for Medicine으로부터 COVID-19 pandemic 이 전에 구입한 Normal human serum을 사용하였다. 시험에 사 용한 모든 검체들은 $90 \mu \mathrm{L}$ 의 완충액과 혼합하여 $100 \mu \mathrm{L}$ 로 만들 었으며 test kit에 점적하고 10 분 후 결과를 측정하였다.

\section{결 과}

1. COVID-19 Spike RBD 영역의 재조합 유전자

합성한 $\mathrm{DNA}$ 를 사용하여 제작하고자 하는 아미노산 서열에 대한 정보는 각각 Figure $1 \mathrm{~A}$, Figure $1 \mathrm{~B}$ 와 같다. 합성한 COVID-19 바이러스의 S1 RBD영역의 DNA는 PCR산물은 $669 \mathrm{bp}$ 임을 확인하였으며(Figure 2A), 증폭한 RBD 유전자를 사용하여 제작한 vector를 $E$. coli $(\mathrm{DH} 5 \alpha)$ 에 형질전환 후 순수 분리한 결과물을 제한효소(HindIII와 $K p n$ I)처리를 하여 확인 한 결과 $\mathrm{RBD}$ 영역 유전자의 $\mathrm{pCMV}$ plasmid vector 삽입된 것 을 확인했다(Figure 2B).

Table 2. Test results of the LFA kits, validated with normal serum samples from Precision for Medicine

\begin{tabular}{ccc}
\hline The No. of tested normal serum samples & Sum \\
\hline \multicolumn{2}{c}{100} & 100 \\
\hline Positive results & Negative results & Sum \\
\hline 0 & 100 & 100 \\
\hline
\end{tabular}

The results of normal serum suggested that there were no proteins or materials within the normal serums, causing non-specific binding with the developed recombinant RBD protein.

\section{COVID-19 Spike 1 RBD재조합 단백질의 제작}

항생제로 선택한 세포에서 분리한 plasmid DNA를 염기서 열 확인을 통해 재조합 RBD 단백질을 발현하는 세포주를 확보 하고 무혈청 배지에서 배양하였다. 원심분리한 배양액 상층액 을 농축하여 니켈 레진으로 정제하여 단백질을 회수한 결과 평 균적으로 얻을 수 있는 재조합 단백질의 양은 배지 $1 \mathrm{~L}$ 당 $0.1 \mathrm{mg}$ 였다. 또한 재조합 RBD 단백질과 시중에 판매 중에 있는 COVID-19 바이러스의 S1 단백질의 일부 아미노산이 포함된 $\mathrm{RBD}$ 단백질을 SDS-PAGE로 비교하여 단백질 마커와 대조하 였을 때 이 연구를 통해 개발된 RBD단백질은 $35 \mathrm{kDa}$ 이였음을 확인하였고 추정 순도는 $97 \%$ 이였다(Figure 3). 구입한 RBD 단
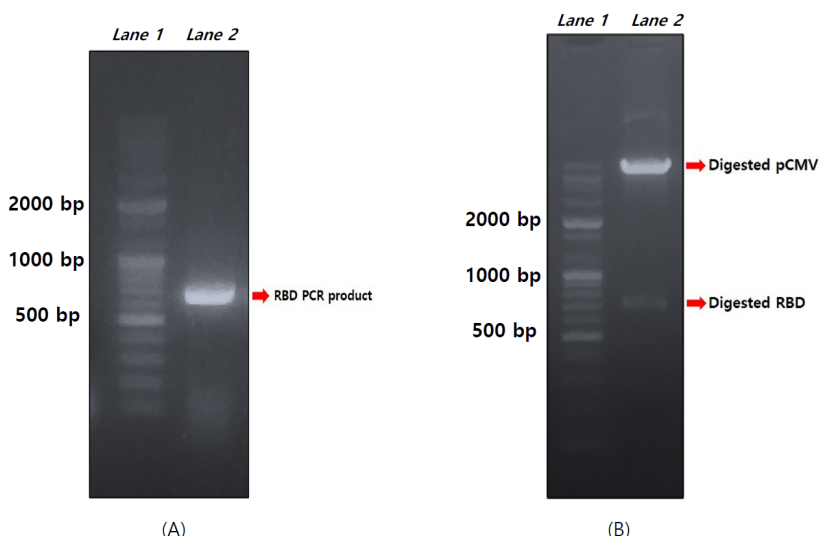

(B)

Figure 2. The electrophoresis result of RBD PCR product (A) and the digested recombinant plasmid by the restriction enzymes (B), respectively. The control ladder was also analyzed to evaluate size of them. The electrophoresis for RBD PCR product result showed that the size of the sequence is $669 \mathrm{bp}$, compared to control ladder (A). The other result showed that sizes of the digested vector (pCMV) and RBD product were around $5000 \mathrm{bp}$ and $700 \mathrm{bp}$, respectively (B).

(A) DNA Sequence of RBD

(B) Amino Acid Sequence of RBD

\section{RVQPTESIVRFPNITNLCPFGEVFNATRFASVYAWNRKRISNCVADYSVLYNSASFSTFKCYGVSPTKLNDLCFTNVYADSFVIRGDEVRQIAPG QTGKIADYNYKLPDDFTGCVIAWNSNNLDSKVGGNYNYLYRLFRKSNLKPFERDISTEIYQAGSTPCNGVEGFNCYFPLQSGFQPTNGVGYQP YRVVVLSFELLHAPATVCGPKKSTNLVKNKCVNF}

Figure 1. DNA sequence of the RBD region (A) and amino acid sequence of RBD (B). DNA sequence of the target region could be found via open research about COVID-19 (A) and if the sequence were translated, RBD protein of the depicted sequence would be produced (B). 
백질은 $54 \mathrm{kDa}$ 임을 확인하였다(Figure $4 \mathrm{~A}$ ). 그리고 RBD에 대 한 특이적인 항체를 사용하여 western 및 dot blotting을 통해 두 재조합 단백질 모두 변성(Figure 4B) 및 3차 아미노산 구조 (Figure 4C)에서 RBD항체에 대하여 특이적으로 반응하는 것 을 확인하였다. 개발된 재조합 단백질은 발현한 단백질의 크기

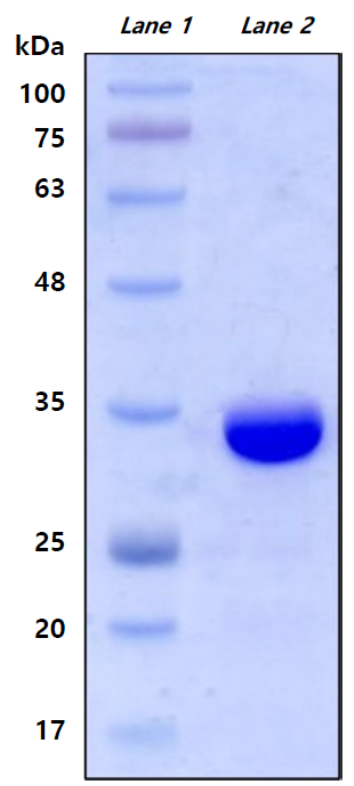

Figure 3. The electrophoresis result for the purified recombinant RBD protein. The RBD recombinant antigen purification followed by SDS-PAGE was undergone to analyze size of the protein. Throughout the size analysis, we found that the recombinant RBD protein is 35 kDa (Lane 2), compared to control (Lane 1). Considering, there would be no bands at all except for the target protein, a purity of the recombinant RBD antigen would be higher than $97 \%$.
가 예상한 것과 같고 western 및 dot blotting의 결과를 분석하 였을 때 RBD 단백질의 3 차 구조와 생물학적 활성을 갖고 있다 는 것을 확인하였다.

\section{LFA 키트의 민감도, 특이도 검사}

골드나노입자와 chicken IgY 및 anti-human IgG를 접합 할 때 최적의 조건은 두 항체 모두 $\mathrm{pH} 6.5$, 항체의 농도가 1.5 $\mathrm{mg} / \mathrm{mL}$ 일 때였다. 해당 조건에서 제작한 두 종류의 접합체를 conjugate pad에 처리하여 건조기에서 건조하여 사용하였고 $\mathrm{LFA}$ 의 검사선에 개발한 재조합 RBD 항원을 분주하여 임상 검 체 내에 COVID-19 바이러스의 S1 RBD단백질에 대한 중화항 체가 있을 시 LFA 키트의 검사선에서 발색이 일어나도록 하였 다. 제작한 LFA 키트에 대한 민감도와 특이도를 검사하기 위하 여 Precision Medicine으로부터 구입한 COVID-19 pandemic 이전 음성 검체(normal human serum, Precision Medicine, USA) 100 개와 Genscript (USA)사의 $\mathrm{cPass}^{\mathrm{TM}}$ SARS-CoV-2 Neutralization Antibody Detection Kit를 사용하여 양성으로 확인된 양성 검체 panel을 영국의 NIBSC에 서 분양 받아 $3.8 \mathrm{AU} / \mathrm{mL}$ 미만을 음성 control (13 samples)로 판정하고 $3.8 \mathrm{AU} / \mathrm{mL}$ 이상을 양성 control (24 samples)로 설 정하여 민감도와 특이도를 테스트한 결과 양성 일치율, positive percent agreement (PPA) 100\%, 음성 일치율, negative percent agreement (NPA) $98.3 \%$, limit of detection (LOD)은 $29.1 \mathrm{AU} / \mathrm{mL}$ 의 결과를 얻을 수 있었다 (Table 3).

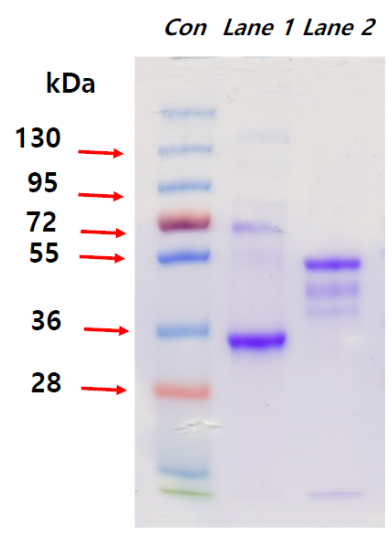

(A)

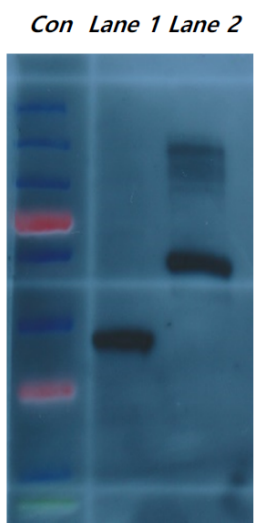

(B)

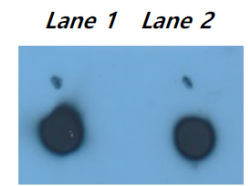

(C)

Figure 4. The electrophoresis and membrane blotting results compared with other RBD protein. The developed RBD antigen (Lane 1) and previously marketed RBD antigen (Lane 2) were undergone comparison analysis in terms of size. When electrophoresis results of the both RBD recombinant antigens were stained, it was observed that the size of the previously marketed RBD antigen is larger than the developed recombinant antigen (A). Moreover, when the gel of the SDS-PAGE was transferred to a membrane treated with an antibody for COVID-19 $\mathrm{RBD}$, both bands could be transferred to the membrane (B), this means that the RBD protein on the membrane specifically binds to anti-RBD antibody. The dot blotting results suggested that both proteins could be recognized by RBD antibodies even in 3D structure (C). 
Table 3. The NAb concentrations of the tested 37 positive samples from NIBSC

\begin{tabular}{|c|c|c|c|c|}
\hline \multicolumn{2}{|c|}{ Result } & \multicolumn{3}{|c|}{ Control } \\
\hline & & Positive & Negative & Sum \\
\hline \multirow[t]{3}{*}{ Study } & Positive & $22(\mathrm{a})$ & 2 (b) & $24(a+b)$ \\
\hline & Negative & $0(\mathrm{c})$ & $\begin{array}{c}100(\text { PM })(d) \\
13(<3.8, \text { NIBSC) (d) }\end{array}$ & $113(c+d)$ \\
\hline & Sum & $22(a+c)$ & $115(b+d)$ & $137(a+b+c+d)$ \\
\hline
\end{tabular}

The evaluation of relative clinical sensitivity (positive percent agreement; PPA) and specificity (negative percent agreement; NPA) of the recombinant RBD antigen applied LFA kits compared to a previously marketed NAb detection kit (confidence interval; $\mathrm{Cl}=95 \%$ ). Agreement is assessed in terms of Cohen's kappa; Kappa statistic must be at or in excess of $80 \%$.

- PPA $(\%)=100 \times a /(a+c): 100 \%$. N NPA $(\%)=100 \times d /(b+d): 98.3 \%$. · Overall rate of Agreement $(\%)=100 \times(a+d) /(a+b+c+d): 98.5 \%$.

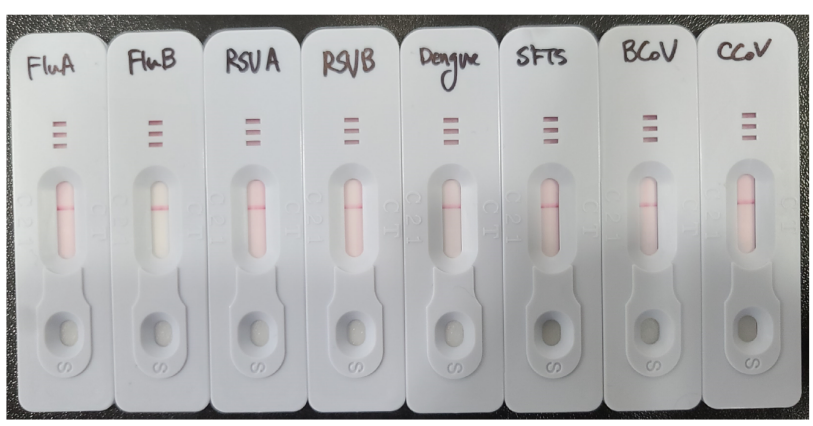

Figure 5. Specificity validation of recombinant RBD protein as LFA format. The developed proteins were applied on the 'test line' of LFA kits and these kits were tested with a group of normal 8 types of monoclonal antibodies. The negative LFA results with 8 types of monoclonal antibodies implied that the protein could not recognize those antibodies at all.

또한 판매하는 8종의 단일클론 항체(influenza A, influenza $\mathrm{B}$, respiratory syncytial virus A (RSV A), respiratory syncytial virus B (RSV B), dengue virus, severe fever with thrombocytopenia syndrome virus (SFTSV), bovine coronavirus, canine coronavirus)에 대하여 비특이 반응 여 부를 실험한 결과 중화항체가 아닌 다른 항체와 비특이적으로 결합하는 것을 확인할 수 없었다(Figure 5).

\section{고 찰}

SARS-CoV-2 또는 COVID-19라고 불리는 신종 코로나 바 이러스는 외막을 갖는 단일 가닥 RNA 바이러스로, 중국 우한지 역에 위치한 병원에서 처음 학계에 보고된 이후 $\mathrm{WHO}$ 에 의해 'pandemic' 등급을 받은 질병이다[1, 2, 15]. 현재까지도 많은 사회적 경제적 문제를 야기하는 COVID-19의 병리학적 연구 를 통해 COVID-19 바이러스의 발병 기전의 시작이 숙주의 $\mathrm{ACE} 2$ 와 바이러스의 결합에 있다는 것을 발견하였으며, 이것에 기반한 백신연구가 활발히 진행되었다[16, 17]. 몇 국가에서는
임상을 진행중인 백신에 대하여 접종을 실시하였으나, 백신 원 재료의 공급이 예상만큼 원활하지 못하여 각 국가마다 계약한 수의 백신을 공급받기까지 시간이 지연되고 있어 아직까지도 COVID-19에 대한 경각심을 풀 수는 없는 상황이다[18-20]. 이런 상황에서 COVID-19에 의해 소모되는 의료인력 및 설비 를 최대한 효율적으로 사용하고, 백신이 충분히 보급된 이후 백 신에 대한 사후조사에 대한 연구를 원활하게 진행하기 위해서 기존 검사법보다 중화항체를 빠르게 검사할 수 있는 키트에 대 한 필요성이 대두되는 상황이다[14, 20, 21]. 본 연구를 통해 이 루고자 하는 것은 COVID-19 바이러스에 대한 중화항체에 특 이적으로 결합이 가능한 항원의 개발과 이것을 사용하여 만든 LFA 기반의 현장 검진 키트, point of care test (POCT) 또는 신속진단 키트의 성능평가다.

COVID-19의 중화항체에 특이적으로 결합하는 재조합 항원 을 만드는 것은 COVID-19 바이러스의 병리학적 기전 및 백신 의 작용기전에 대하여 이해하는 것에 기반하여야 한다. 기존에 진행된 많은 COVID-19 바이러스에 대한 연구를 통해, COVID-19 바이러스에 대한 중화항체 작용 기전은 바이러스 입자가 감염자의 폐 상피세포에 많이 존재하는 $\mathrm{ACE} 2$ 를 통해 세 포 내 이입하는 것을 막는 것임을 알 수 있었으며, 바이러스의 S 단백질 중, S1 subunit은 숙주 세포의 ACE2 수용체에 대하여 바이러스가 결합하는 것을 매개하는 receptor-binding domain (RBD)을 포함한다. 중화항체는 ACE2 수용체와 RBD 사이에 작용하여 COVID-19 바이러스의 감염 기전을 막는 것 으로 중화항체에 특이적인 S 단백질의 S1 영역 중 RBD 영역에 대한 유전자 서열은 NCBI에서 검색하여 선정하였고 $\mathrm{DNA}$ 합성 한 후 목표 유전자 서열을 PCR을 통해 $669 \mathrm{bp}$ 에서 증폭 한 $\mathrm{DNA}$ 를 확보할 수 있었다(Figure 2). 또한 증폭된 DNA의 서열 분석을 통해, 실험에서 제작한 유전자 서열이 의도한 것과 같이 5'과 3'에 각각 Hind 111 효소와 $K p n 1$ 효소 절단부위를 포함하 는 것을 확인할 수 있었다. 증폭된 DNA를 사용하여 재조합 
plasmid를 제작 후 E. coli $(\mathrm{DH} 5 \alpha)$ 에 형질전환하여 목표 유전 자가 확인되는지 제한효소 절단을 통해 확인한 결과, Figure $1 \mathrm{~B}$ 처럼 $5 \mathrm{kbp}$ 및 $700 \mathrm{bp}$ 근처에서 밴드가 나오는 것을 확인할 수 있었고 유전자 크기에 대한 정보에 근거하여 각 밴드는 $\mathrm{pCMV}$ vector와 RBD 유전자임을 알 수 있었다. 재조합 plasmid를 HEK293 세포에 형질주입 한 후 항생제에 내성이 있는 형질전 환 된 세포를 배양해서 배양액을 $30 \%(\mathrm{w} / \mathrm{v})$ 황산암모늄 수용액 으로 처리하여 농축하고 니켈 레진으로 단백질을 정제하였다, 이러한 단백질을 SDS-PAGE를 통해 전기영동 하여 회수한 단 백질의 순도와 크기를 확인하였다. 전기영동하여 단백질의 크 기가 $35 \mathrm{kDa}$ 임을 확인하였고 계산을 통해 그순도가 $97 \%$ 이상 임을 확인할 수 있었다(Figure 3). 이 크기는 아미노산 서열을 예측한 결과에 기반하여 $25 \mathrm{kDa}$ 이 나올 것이라고 예측한 것과 는 다른데 이는 재조합 RBD 단백질이 당화되어 기존에 예상한 분자량보다 크기가 크게 나왔다 추정한다[22, 23].

개발된 재조합 단백질이 목표로 하는 단백질이 맞는지를 확 인하기 위하여 개발된 재조합 단백질과 시판 중인 RBD 단백질 을 western blot과 spot blot을 하여 개발된 재조합 단백질이 변성 여부에 상관없이 기존에 시판 중인 RBD 단백질과 같이 단 일클로날 RBD 단백질 항체와 특이적으로 결합한다는 것을 확 인하였다(Figure 4).

이 단백질이 COVID-19 중화항체에 특이적인 생물학적 활 성을 갖고 있는지 확인하기 위해서 통상적인 항체 진단용 LFA 와 같은 구조의 신속 진단 키트를 제작하였다. 이를 위해서 membrane 상의 control line과 test line에 분주할 단백질의 양을 정하고, gold pad에 처리할 골드 나노 입자와 결합체를 형 성할 항체와의 결합 조건 및 처리할 양을 결정하기 위하여 키트 의 검사선 위치에 개발한 단백질의 최적의 분주량을 $1,1.5,2$ $\mathrm{mg} / \mathrm{mL}$ 농도로 희석하여 분주하였고 이 조건 중 가장 감도가 높 은 $2 \mathrm{mg} / \mathrm{mL}$ 의 농도로 $\mathrm{cm}$ 당 $30 \mu \mathrm{L}$ 의 양으로 분주량을 결정하 였다.

또한 conjugate pad에 처리할 anti-human IgG와 chicken IgY를 각각 골드 나노 입자와 결합한 conjugate의 제작 조건을 확인하기 위하여 $\mathrm{pH}$ 와 단백질의 양을 적정을 통해 antihuman IgG (Bore Da Biotech, Clone \#K3E7)와 chicken IgY (Lampire, PA, USA)를 pH 6.5인 골드 나노 입자에 $1.5 \mu$ $\mathrm{g} / \mathrm{mL}$ 의 농도로 혼합하였을 때 최적의 결합체의 반응 조건인 것 을 확인하였다. conjugate pad에 conjugate를 처리하는 양에 따른 민감도의 차이를 확인하여 최적의 처리 용량을 처리하였 다. 이렇게 pad에 처리한 gold conjugate의 총량은 $450 \mu \mathrm{L}$ 으 로서, anti-human IgG gold conjugate $400 \mu \mathrm{L}$ 와 chicken
IgY gold conjugate $50 \mu \mathrm{L}$ 의 혼합액이다. 이것을 $6 \mathrm{~mm} \times 30$ $\mathrm{cm}$ 크기의 glass fiber grade 8964 (Ahlstrom-Munksjö, Helsinki, Finland) 처리하여 conjugate pad를 제작하였다.

신속 진단 키트를 제작할 때, 시료패드의 처리 방식이 다른 네 종류의 키트를 제작하였고 각 키트의 민감도와 특이도의차이를 확인하여 시료패드 처리 조건에 따라 양성 검체의 감도차이를 확인하였다. 시료패드를 $10 \mathrm{mM}$ borate buffer, $0.1 \%$ casein, $0.5 \%$ triton X-100로 처리하였을 때 음성 검체에서 비 특이적 반응이 관찰되지 않았고 양성 검체의 검출감도가 가장 좋았다. 이러한 처리 조건을 바탕으로 개발한 신속 진단 키트에 COVID-19 바이러스에 대한 중화항체를 포함하는 NIBSC (UK) 양성 검체를 원래 농도의 $1 / 10$ 로 희석하여 반응시켰고, 그 결과로 신속 진단 키트의 최소 검출 한계는 $29.1 \mathrm{AU} / \mathrm{mL}$ 이 며, 샘플 중 그보다 낮은 농도인 $16.9 \mathrm{AU} / \mathrm{mL}$ 검체에서는 음성 으로 나타난다는 것을 확인하였다. 이는 본 논문을 통하여 개발 한 RBD 단백질이 신속 진단 키트로 제작했을 때 최소 검출 한계, limit of detection (LOD)가 16.9에서 29.1 AU/mL 사이라는 것을 의미한다.

또한 COVID-19 이전에 확보된 100종의 혈청을 신속 진단 키트로 테스트했을 때 $100 \%$ 음성의 결과를 보였다(Table 2). 이는 재조합 단백질이 정상 혈청 내 존재할 수 있는 면역 단백질, 항체, 및 혈구 세포 등에 대하여 비 특이적으로 반응하지 않는 것 을 알수 있다. 또한 코로나바이러스 및 호흡기 질환 유발 바이러 스에 대한 항체를 포함한 총 8종의 항체를 신속 진단 키트에 반 응시켰을 때, 모든 항체에 대하여 음성 결과로서 나타나는 것을 확인할 수 있었다(Figure 5).

이는 신속 진단 키트가 COVID-19 바이러스의 중화항체 이 외의 항체들에 대하여 교차반응이 없다는 것을 뜻한다. 개발한 재조합 단백질과 그를 이용한 신속 진단 키트는 효율적인 백신 접종자의 효율적 관리로의 적용을 위해서 추가 연구를 통하여 좀더 다양한 중화항체를 포함하는 백신접종자 및 감염 후 완치 환자의 임상 혈청샘플들을 분석해 통계학적 신뢰성을 높일 필요 가 있으며 신속 진단 키트의 민감도와 특이도를 개선하고 정량 분석장비를 통하여 항체가를 수치로 표시되어 사용자 편의성을 개선한다면 현장진단용 중화항체 진단 키트로 제품화 가능성이 높다고 생각한다.

\section{요 약}

코로나바이러스감염증-19는 사람의 호흡기관에 다수로 분 포하는 안지오텐신전환효소2, angiotensin converting 
enzyme 2 (ACE2)를 매개하여 감염을 일으키는 $\beta$-genus 바이 러스이고 완치환자 및 백신 접종자의 항체생성에 대한 효율적인 사후관리가 필요한 질병을 유발하는 바이러스다. 이 논문에서 는 임상 시료의 중화항체와 특이적으로 반응하는 재조합 단백질 을 개발하고 이를 이용하여 COVID-19 바이러스에 대한 중화 항체를 빠르고 편리하게 진단하는 신속 진단 키트를 개발하고 그것의 성능 평가를 통하여 제품화 가능성을 확인하는 것을 목 표로 하였다. COVID-19 S1 RBD 재조합 단백질을 사용한 신 속 진단 키트의 양성 퍼센트 일치(PPA) 및 음성 퍼센트 일치 (NPA)가 미국 FDA EUA에서 승인한 ELISA 키트와 비교했을 때 각각 $100 \%$ 및 $98.3 \%$ 인 점에서 신속 진단 키트에 적용할 수 있을 것으로 확인하였다. 향후 신속 진단 키트의 성능을 개선하 고 정량 분석 장비를 통해 중화항체를 정량적으로 분석이 가능 하면 제품화 통해 검체내의 중화항체 유무와 양을 확인함으로써 COVID-19 바이러스에 대한 면역성을 예측하고 추가 예방접 종 여부를 판단하는 중요한 자료로 활용될 수 있을 것으로 생각 한다.

Acknowledgements: We thank Lee KM, professor of Department of Chemical Engineering \& Biotechnology, Korea Polytechnic University (Korea, Gyeonggi-do) to help of advisory works to accomplish overall experimental designs.

\section{Conflict of interest: None}

Author's information (Position): Choi DO, Graduate student; Lee KM, Professor.

\section{REFERENCES}

1. Muniyappa R, Gubbi S. COVID-19 pandemic, coronaviruses, and diabetes mellitus. Am J Physiol Endocrinol Metab. 2020;318: E736-741. https://doi.org/10.1152/ajpendo.00124.2020

2. King RG, Silva-Sanchez A, Peel JN, Botta D, Meza-Perez S, Allie R, et al. Single-dose intranasal administration of AdCOVID elicits systemic and mucosal immunity against SARS-CoV-2 in mice. bioRxiv [Preprint]. 2020;11:2020.10.10.331348. https://doi.org/10. $1101 / 2020.10 .10 .331348$

3. World Health Organization (WHO). WHO COVID-19 Dashboard [Internet]. Geneva: World Health Organization; 2020. [cited 2021 March 17]. Available from: https://covid19.who.int/

4. Dong E, Du H, Gardner L. An interactive web-based dashboard to track COVID-19 in real time. Lancet Infect Dis. 2020;20:533-534. https://doi.org/10.1016/S1473-3099(20)30120-1

5. Gorbalenya AE, Baker SC, Baric RS, de Groot RJ, Drosten C, Gulyaeva AA, et al. The species severe acute respiratory syndrome-related coronavirus: classifying 2019-nCoV and naming it
SARS-CoV-2. Nat Microbiol. 2020;5:536-544 https://doi.org/ 10.1038/s41564-020-0695-z

6. Chan JF, Yuan S, Kok KH, To KK, Chu H, Yang J, et al. A familial cluster of pneumonia associated with the 2019 novel coronavirus indicating person-to-person transmission: a study of a family cluster. Lancet. 2020;395:514-523. https://doi.org/10.1016/S01406736(20)30154-9

7. Meyerowitz EA, Richterman A, Gandhi RT, Sax PE. Transmission of SARS-CoV-2: a review of viral, host, and environmental factors. Ann Intern Med. 2021;174:69-79. https://doi.org/10.7326/ M20-5008

8. Zou L, Ruan F, Huang M, Liang L, Huang H, Hong Z, et al. SARS-CoV-2 viral load in upper respiratory specimens of infected patients. N Engl J Med. 2020;382:1177-1179. https://doi. org/10.1056/NEJMc2001737

9. Huang Y, Yang C, Xu XF, Xu W, Liu SW. Structural and functional properties of SARS-CoV-2 spike protein: potential antivirus drug development for COVID-19. Acta Pharmacol Sin. 2020;41:11411149. https://doi.org/10.1038/s41401-020-0485-4

10. Bourgonje AR, Abdulle AE, Timens W, Hillebrands JL, Navis GJ, Gordijn SJ, et al. Angiotensin-converting enzyme 2 (ACE2), SARS-CoV-2 and the pathophysiology of coronavirus disease 2019 (COVID-19). J Pathol. 2020;251:228-248. https://doi.org/ 10.1002/path. 5471

11. Connors M, Graham BS, Lane HC, Fauci AS. SARS-CoV-2 vaccines: much accomplished, much to learn. Ann Intern Med. 2021;174:687-690. https://doi.org/10.7326/M21-0111

12. Chung YH, Beiss V, Fiering SN, Steinmetz NF. COVID-19 vaccine frontrunners and their nanotechnology design. ACS Nano. 2020;14:12522-12537. https://doi.org/10.1021/acsnano.0c07197

13. Custers J, Kim D, Leyssen M, Gurwith M, Tomaka F, Robertson J, et al. Vaccines based on replication incompetent $\mathrm{Ad} 26$ viral vectors: standardized template with key considerations for a risk/benefit assessment. Vaccine. 2021;39:3081-3101. https://doi. org/10.1016/j.vaccine.2020.09.018

14. Muruato AE, Fontes-Garfias CR, Ren P, Garcia-Blanco MA, Menachery VD, Xie X, et al. A high-throughput neutralizing antibody assay for COVID-19 diagnosis and vaccine evaluation. Nat Commun. 2020;11:4059. https://doi.org/10.1038/s41467-02017892-0

15. Morens DM, Folkers GK. What is a pandemic? J Infect Dis. 2009;200:1018-1021. https://doi.org/10.1086/644537

16. Boopathi S, Poma AB, Kolandaivel P. Novel 2019 coronavirus structure, mechanism of action, antiviral drug promises and rule out against its treatment. J Biomol Struct Dyn. 2021;39:34093418. https://doi.org/10.1080/07391102.2020.1758788

17. Speiser DE, Bachmann MF. COVID-19: Mechanisms of vaccination and immunity. Vaccines (Basel). 2020;8:404. https://doi. org/10.3390/vaccines8030404

18. Polack FP, Thomas SJ, Kitchin N, Absalon J, Gurtman A, Lockhart S, et al. Safety and efficacy of the BNT162b2 mRNA covid-19 vaccine. N Engl J Med. 2020;383:2603-2615. https://doi.org/10. 1056/NEJMoa2034577

19. Voysey M, Clemens SAC, Madhi SA, Weckx LY, Folegatti PM, Aley $\mathrm{PK}$, et al. Safety and efficacy of the ChAdOx1 $\mathrm{nCoV}-19$ vaccine (AZD1222) against SARS-CoV-2: an interim analysis of four randomised controlled trials in brazil, south africa, and the UK. 
Lancet. 2021;397:99-111. https://doi.org/10.1016/S0140-6736(20) 32661-1

20. Torjesen I. Covid-19 vaccine shortages: what is the cause and what are the implications? BMJ. 2021;372:n781. https://doi. org/10.1136/bmi.n781

21. Micocci M, Gordon AL, Allen AJ, Hicks T, Kierkegaard P, McLister $A$, et al. COVID-19 testing in english care homes and implications for staff and residents. Age Ageing. 2021;50:668-672. https://doi. org/10.1093/ageing/afab015
22. Bosch BJ, van der Zee R, de Haan CA, Rottier PJ. The coronavirus spike protein is a class I virus fusion protein: structural and functional characterization of the fusion core complex. J Virol. 2003;77:8801-8811. https://doi.org/10.1128/jvi.77.16.8801-8811. 2003

23. Shajahan A, Supekar NT, Gleinich AS, Azadi P. Deducing the Nand O-glycosylation profile of the spike protein of novel coronavirus SARS-CoV-2. Glycobiology. 2020;30:981-988. https://doi. org/10.1093/glycob/cwaa042 